Revista Brasileira de Ecoturismo, São Paulo, v.1, n.1, setembro, 2008. ISSN: 1983-9391 - SEÇÃO: ARTIGOS

Costa, V.C.; Triane, B.P.; Costa, N.M.C. Impactos ambientais em trilhas: agricultura X Ecoturismo um estudo de caso na Trilha do Quilombo (PEPB-RJ). Revista Brasileira de Ecoturismo, São Paulo, v.1, n.1, 2008, pp.84-113.

\title{
Impactos ambientais em trilhas: agricultura X Ecoturismo - um estudo de caso na Trilha do Quilombo (PEPB-RJ)
}

\section{Vivian Castilho da Costa, Beatriz Pereira Triane, Nadja Maria Castilho da Costa}

\begin{abstract}
RESUMO
O Ecoturismo, apesar de ter crescido o seu número de adeptos no Brasil, vem sofrendo com o pouco ordenamento da visitação em grande parte de suas Unidades de Conservação. As suas trilhas demonstram-se como um dos maiores atrativos (contato com os ambientes naturais para lazer e prática de esportes), mas, devido a falta de planejamento e manejo mais adequado vem sofrendo com impactos ambientais. Os estudos referentes às trilhas e aos impactos dos seus diferentes usos são importantes na medida em que uma vez estabelecidas em UCs, as trilhas possuem papel crucial no manejo do meio ambiente onde está inserida. O presente artigo parte da premissa que o uso freqüente e intensivo de trilhas como local de passagem da produção agrícola de pequenos sitiantes que residem no interior da segunda maior Unidade de Conservação do município do Rio de Janeiro localizada na zona oeste - o Parque Estadual da Pedra Branca (PEPB) - pode causar impacto erosivo no solo, estabelecendo desta forma, uma contradição com a finalidade de sua preservação, estabelecida pelo SNUC, (2000). Portanto, este estudo proporcionou um melhor conhecimento e diagnóstico dos impactos erosivos de uma de suas principais trilhas (próxima à sede) chamada trilha do Quilombo que foi analisada sob a ótica geográfica para o planejamento ambiental de suas atividades ecoturísticas.
\end{abstract}

\section{PALAVRAS-CHAVE}

Impactos Ambientais, Ecoturismo, Trilhas.

\section{Environmental Impacts on trails: agriculture $X$ ecotourism - the case of "Trilha do Quilombo" (PEPB) - Rio de Janeiro - Brazil}

\section{ABSTRACT}

The ecotourism, despite having increased its number of fans in Brazil, is suffering with the poor plannification of visitation in protected areas. Their trails show up as one of the biggest attractions (contact with the natural environment for recreation and practice of sports), but due to lack of proper planning and management more suffering comes with environmental impacts. The studies concerning the trails and the impact of its different uses are important in that once established in protected areas, the trail have a crucial role in the management of the environment where it is inserted. This article show the premise that the frequent and intensive use of trails as a place of passage of agricultural production of small farmers who reside within the second largest protected area located on the west side of Rio de Janeiro county - the Parque Estadual da Pedra Branca (PEPB) - can cause Erosive impact in the soil, thereby setting, a contradiction with the aim of preserving their area, established by the National Protected Area System - SNUC (2000). Therefore, this study provided a better understanding and diagnosis of erosive impact of one of its main tracks (near the headquarters) called the Quilombo trail that was analyzed from the perspective for the geographical planning of its ecotouristic activities.

\section{KEY-WORDS}

Environmental Impacts, Ecotourism, Trails. 
Impactos ambientais em trilhas: agricultura X Ecoturismo - um estudo de caso na Trilha do Quilombo

\section{Introdução}

O aumento do número de pessoas buscando o convívio direto com a natureza através de atividades ao ar livre faz com que a discussão dos impactos causados pela visitação em áreas naturais seja, atualmente, de extrema importância, principalmente quando se trata de Unidades de Conservação no Brasil.

Nos últimos anos, houve um crescimento das atividades ligadas ao turismo de natureza no Brasil e com isso as áreas protegidas têm se tornado um grande atrativo às pessoas que procuram essa alternativa de lazer.

Segundo Machado (2003, p. 29), o turismo de natureza precisa ser repensado para garantir a sua qualidade como produto e tornar segura ao local ao qual se destina, principalmente para evitar desgastes "desnecessários e investimentos inadequados, passíveis de gerar insatisfação e descrédito".

Uma das modalidades do turismo de natureza é o Ecoturismo. Porém, este vem sendo confundido com outras modalidades como o turismo alternativo e de aventura, mas, que diferentes deste último, não possuem processo de ordenação da visitação e, nem mesmo há uma integração entre as suas atividades com a comunidade local. Portanto, o mínimo impacto muitas vezes não é observado na utilização do ambiente pelo turismo de aventura ou pelo turismo alternativo e suas atividades podem trazer sérios problemas ao próprio meio ambiente.

De acordo com a Sociedade Internacional de Ecoturismo (The Internacional Ecotourism Society - TIES) uma Organização Não Governamental (ONG) dos EUA, o Ecoturismo é "a viagem responsável a áreas naturais, visando preservar o meio ambiente e promover o bem-estar da população local" (HAWKINS; KAHN, 2001; DALE, 2005).

No Brasil, o Ecoturismo é considerado uma atividade de pequeno porte, no contexto da economia brasileira, representando, aproximadamente, $1 \%$ do mercado de turismo. Mas, a situação é diferente nos países desenvolvidos, onde o Ecoturismo representa uma parcela mais significativa do mercado turístico, de 10 a 15\%, segundo Meirelles Filho (2005).

Contudo, as oportunidades de negócios são inúmeras, e o setor vem apresentando forte crescimento. O "negócio ecoturístico" pode proporcionar, segundo Meirelles Filho (2005), uma série de "benefícios", sendo capaz, inclusive, de garantir a sua auto-sustentabilidade.

Desta forma, observa-se de um lado a busca social pelo contato com a natureza e, de outro, a necessidade de preservação da mesma através da proibição ou restrição de usos pelo homem. Com isso, há necessidade de se compreender as relações existentes entre sociedade, homem e natureza e como tal se materializa no espaço geográfico.

Neste contexto, a Geografia possui papel de suma importância visto que um dos temas propostos e mais discutidos, atualmente, refere-se à questão ambiental. Esta, além de se constituir numa das preocupações deste início de século, proporciona a compreensão dialética das relações entre homem e natureza. Nas 
últimas décadas, a Geografia, principalmente a Geografia Física, está enfocada sobremaneira na temática ambiental, principalmente em estudos feitos sobre o meio ambiente e sua dinâmica, incluindo-se aí a atuação humana sobre seus demais elementos constituintes.

As escalas onde ocorre a degradação do meio ambiente variam numa complexidade inerente à própria natureza, se manifestando na escala global, como por exemplo, a intensificação do efeito estufa, até o desencadeamento de processos erosivos em trilhas de uma Unidade de Conservação, numa escala local.

De acordo com Seabra (1999), se observa no Brasil uma escassez de trabalhos científicos sobre impactos ambientais em Unidades de Conservação, logo, se observa uma deficiência no estudo dos impactos causados pelo uso indiscriminado das trilhas no interior dos ambientes protegidos. Sendo assim, a escala adotada no presente estudo é a trilha, pois se tem conexão direta do homem com a natureza.

As trilhas, por serem mais utilizadas para fins recreativos, permitem o acesso aos atrativos e às áreas mais interioranas das Unidades de Conservação e, por isso, possuem importância considerável no planejamento e manejo do uso público. Segundo Costa (2004, p.9): "as trilhas devem ser criteriosamente localizadas, planejadas, construídas e manejadas de modo a permitir a conservação dos recursos naturais e a realização de contatos adequados pelos visitantes".

A freqüente busca dos estudiosos sobre as atividades desenvolvidas no interior de Unidades de Conservação tem por finalidade tentar descrever os tipos e as taxas de mudanças ambientais, resultados dos diversos usos existentes em cada área protegida.

A relação entre o tipo de uso, o ambiente e os fatores de manejo devem ser devidamente estudados e relacionados para uma melhor compreensão da dinâmica ambiental. Grande parte dos impactos em trilhas ocorre por diferentes motivos. Segundo Schelhas apud Andrade (2005, p.132), podem ocorrer impactos simplesmente em razão de seu abandono, ou seja, para tentar "evitar necessários ziguezagues, obstáculos e trilhas com superfície formada somente por pedras, ou ainda, a procura pela sensação de 'aventura'", ou seja, o uso inadequado pode ainda criar novos acessos desnecessários ou ainda atalhos e bifurcações amplificando os impactos.

Todas as formas de uso de trilhas contribuem para a pesquisa dos impactos em ambientes protegidos, alguns mais do que outros, visto que algumas atividades são mais impactantes que outras. Estes estudos científicos podem auxiliar os gestores das unidades na identificação das mudanças feitas pelos homens, facilitando desta forma, uma melhor compreensão das causas e dos efeitos, melhorando as introspecções a respeito da prevenção, mitigação, e da gerência dos problemas.

No contexto das atividades realizadas no interior de Unidades de Conservação, as trilhas demonstram-se como um dos maiores atrativos na medida em que oferecem aos visitantes maior contato com os ambientes naturais para lazer e prática de 
Impactos ambientais em trilhas: agricultura X Ecoturismo - um estudo de caso na Trilha do Quilombo

esportes e, por isso exigem um planejamento e manejo mais adequado.

A utilização de trilhas, segundo Andrade (2005), estabelece-se de acordo com diversas finalidades que variam desde procura de alimento e água, ate peregrinações religiosas, viagens comerciais e ações militares, desta forma, uma das suas principais funções é suprir a necessidade de deslocamento de populações locais. O mesmo autor afirma ainda que as trilhas utilizadas para o Ecoturismo, foram utilizadas tradicionalmente para o deslocamento de determinadas comunidades e que no Brasil Colônia, os portugueses já utilizavam os caminhos abertos pelos indígenas para chegarem ao interior do país.

Ao passar dos anos, segundo Costa (2006a, p.3), a finalidade das trilhas vem apresentando uma mudança, "deixando de ser um simples meio de deslocamento, para ser um novo meio de contato com a natureza". Ainda segundo a autora:

A valoração dos caminhos e trilhas de terra (sem calçamento) foi grande e hoje existem vários torneios e competições que testam as habilidades das máquinas e do homem. Muitas dessas atividades, inclusive, são conceituadas, erroneamente como fazendo parte da terminologia do Ecoturismo, mas na realidade, estão mais destinadas ao turismo aventura ou desportivo (COSTA, 2006a, p.4).

A partir das idéias de Costa (2006b), pode-se compreender que a intensidade dos efeitos de uso das trilhas está relacionada com o tipo de atividade praticada e que apenas algumas alterações nestas, como alargamento, acidentes erosivos e composição da flora diferenciada são perceptíveis aos visitantes e gestores de Unidades de Conservação.

Alguns autores, como Salvati (2001), afirmam que a fragilidade dos ecossistemas naturais, muitas vezes, não comporta os usos estabelecidos. Por outro lado, a infra-estrutura necessária, se não atendidas as normas pré-estabelecidas, pode comprometer de maneira acentuada o meio ambiente, com alterações na paisagem, na topografia, no sistema hídrico e na conservação dos recursos naturais florísticos e faunísticos.

Pesquisas sobre os impactos negativos em áreas protegidas estão sendo desenvolvidas comparando os impactos provocados pelos caminhantes, pelo uso de cavalos, pelas motocicletas (motocross) e por mountain bike. Algumas dessas pesquisas têm apontado os impactos sociais como os mais perceptíveis a serem avaliados devido à relação com a experiência do uso dos visitantes, principalmente, o conflito existente entre os diversos usuários e os diferentes usos das trilhas.

Neste contexto, os estudos referentes as trilhas e os impactos dos seus diferentes usos são importantes na medida em que uma vez estabelecida em Unidades de Conservação, as trilhas possuem papel crucial no manejo do meio ambiente onde está inserida.

Para tanto, a presente investigação parte da premissa que o uso freqüente e 
intensivo de trilhas como local de passagem da produção agrícola de pequenos sitiantes que residem no interior da segunda maior Unidade de Conservação do município do Rio de Janeiro localizada na zona oeste - o Parque Estadual da Pedra Branca (PEPB) - pode causar impacto no solo, estabelecendo desta forma, uma contradição com a finalidade potencial das trilhas para o uso ecoturístico.

Deste modo, o presente estudo tem como objetivo geral analisar os impactos erosivos no solo provocados pelo uso intensificado de eqüestres em uma das principais trilhas do PEPB utilizada para escoar grande parte da produção, principalmente de banana, dos sitiantes do interior da Unidade de Conservação (UC), a Trilha do Quilombo. Esta trilha além de possuir um grande potencial para a atividade de Ecoturismo, foi escolhida por apresentar grande susceptibilidade erosiva e média vulnerabilidade à perda de solo (COSTA, 2006a). Os processos erosivos da trilha vêm sendo intensificados pela ação de degradação do uso antrópico (desmatamento de espécies da mata Atlântica, plantio de banana e ocupação irregular nas encostas).

Os objetivos específicos foram inerentes ao diagnóstico de pontos de amostragem na trilha que refletissem o quadro de maior impacto erosivo, visando criar subsídios para o planejamento eficaz de trilhas existentes ou a serem implantadas, além de servir como apoio à gestão e ao manejo efetivo (manutenção e conservação) da UC por parte da administração do PEPB. Esta área piloto foi escolhida, principalmente por ser uma trilha próxima a sede do Parque e servir de visitação para caminhantes que procuram uma alternativa de trilha de mais alto grau de dificuldade $e$ com outros atrativos.

$\mathrm{Na}$ tentativa de alcançar os objetivos propostos, buscou-se, ao longo deste trabalho, responder à seguinte questão central: Quais os pontos mais impactados da trilha e por quê? Desta forma, tal questionamento central acarreta outras indagações secundárias necessárias para a melhor compreensão e aprofundamento da temática proposta, tais como: Que medidas podem ser tomadas para a manutenção da trilha e controle de seus impactos negativos? Quais alternativas podem ser propostas para minimizar os impactos que o uso intensivo está causando na trilha? As medidas a serem tomadas seriam de cunho restritivo ou de conservação.

\section{Parque Estadual da Pedra Branca: testemunho da história de ocupação na zona oeste da cidade do Rio de Janeiro}

O Parque Estadual da Pedra Branca, criado através da Lei Estadual $n^{\circ} 2.377$, de 28 de junho de 1974, está sob a tutela da Fundação Instituto Estadual de Florestas - IEF/RJ e possui aproximadamente $124 \mathrm{~km}^{2}$ de área de Terras, correspondendo a toda área elevada acima da cota $100 \mathrm{~m}$ do maciço do mesmo nome ${ }^{1}$ que se situa na zona oeste do município do Rio de Janeiro. É considerada a segunda mais importante 
Impactos ambientais em trilhas: agricultura X Ecoturismo - um estudo de caso na Trilha do Quilombo

Unidade de Conservação da cidade, abrangendo cerca de 16\% da área do município.

Com aproximadamente $170 \mathrm{~km}^{2}$, o maciço da Pedra Branca faz parte de um conjunto de maciços litorâneos que compõem o relevo da cidade do Rio de Janeiro (COSTA, 1986) ao lado dos Maciços da Tijuca e Gericinó - Mendanha (Figura 1).

Em termos fisiográficos, o maciço da Pedra Branca apresenta altitude moderada, que varia de 50 a 1025 metros, sendo esta última altitude o ponto culminante do município carioca. O Maciço possui vertentes escarpadas, que quando comparadas ao do maciço da Tijuca, apresenta feições de relevo menos dissecadas. Suas encostas são mais entalhadas do que as do maciço Gericinó-Mendanha, devido a diferentes litologias e estruturas (COSTA, 2002).

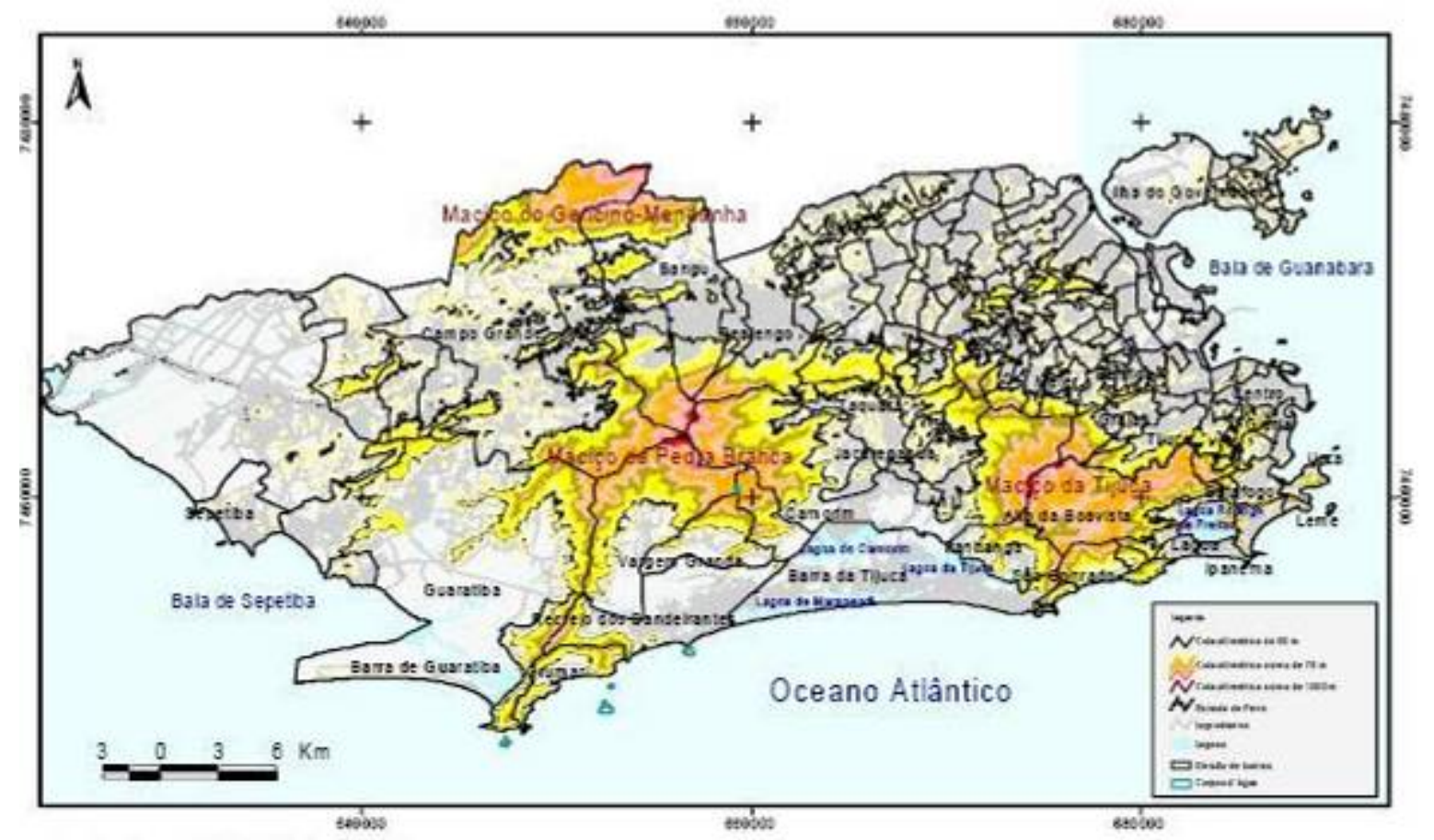

Figura 1 - Mapa de Localização dos Maciços Litorâneos do Município do Rio de Janeiro. Fonte: Elaborado por COSTA (2006a).

O Maciço apresenta uma rica rede hidrográfica, cujos rios são responsáveis pelo abastecimento de água das baixadas circunvizinhas, com destaque para as represas do Pau da Fome e do Camorim, ambas controladas pela Companhia de Água e Esgoto do Estado do Rio de Janeiro (CEDAE). Outras represas situadas na vertente norte e leste, devido aos grandes problemas de desmatamento e poluição que comprometem a qualidade da água, foram desativadas para o abastecimento.

A Mata Atlântica, a exemplo de outros biomas brasileiros, tem sofrido conseqüências de ações nas esferas políticas, econômicas e sociais geradas desde o descobrimento do país. Foram diversos ciclos econômicos calcados na exploração 
predatória dos recursos naturais resultantes de cinco séculos de exploração e expansão da agricultura, além da urbanização ocorrida no país.

Assim, a degradação da Floresta Tropical do Estado do Rio de Janeiro remonta à chegada dos primeiros colonizadores, iniciada com as primeiras explorações de pau-brasil e depois pelos ciclos econômicos da cana-de-açúcar, café, gado, etc. (COSTA, 2006a).

$\mathrm{Na}$ realidade, as áreas montanhosas do litoral do Rio de Janeiro e os maciços litorâneos cariocas mantiveram suas fisionomias originais, quase inalteradas até a metade do século XVII, em virtude da concentração de seus primeiros habitantes próximos à orla marítima.

Com o decorrer da colonização, as encostas começaram a ser devastadas para variados aproveitamentos: obtenção de recursos naturais, alimentação, construção e fonte de energia. Os vales e as encostas foram sendo ocupados por construções e cultivos diversos dando início a fase das grandes fazendas. Mantinhase conservados somente os grotões inacessíveis e áreas de maior declividade.

Nesta época os caminhos e estradas eram abertos pelos fazendeiros, para escoamento da produção, e também pelos jesuítas e beneditinos. As classes dominantes das fazendas, no início do século XIX até meados do século XX, utilizavam as trilhas e caminhos do maciço da Pedra Branca, para cavalgadas, por prazer ou pelas péssimas condições das estradas que tornava necessário o uso do cavalo pelas trilhas.

Em meados do século XX, uma maior pressão aos remanescentes florestas do maciço veio se processando principalmente para retirada de lenha e carvão nas décadas de 1940 a 1960, como relata Freitas et.al. (2005, p.144):

[...] configurando uma atividade econômica significativa, que tinha como finalidade abastecer a malha urbana que se expandia pelas baixadas do Rio de Janeiro. A extração desses produtos ocorria em áreas elevadas, onde não havia sitiantes, promovendo a retirada de vegetação das encostas.

Este autor ainda cita Galvão (1957):

[...] após os ciclos econômicos de grande importância, desenvolveuse, no maciço da Pedra Branca, uma agricultura de subsistência em pequenas propriedades praticada por sitiantes. Com o passar do tempo foram sendo criados pontos de comercialização da produção excedente desses pequenos proprietários, o que acabava por reuni-los na base das encostas, próxima à vargem. (FREITAS et.al.. 2005, p.144):

Bernardes (apud FREITAS et.al., 2005, p.145), também afirma a importância da produção local de subsistência para o abastecimento da cidade, além de relatar como essas atividades econômicas se processavam nas encostas do maciço:

Nas pequenas propriedades onde é praticado o roçado, os principais produtos da serra comercializados são a banana, a laranja, o chuchu, 
Impactos ambientais em trilhas: agricultura X Ecoturismo - um estudo de caso na Trilha do Quilombo

o mamão e as hortaliças tuberosas. A escolha de tais produtos não é aleatória, mas justificada pelo transporte, realizado em lombo de mulas e burros, o que torna delicado para produtos menos resistentes descerem a serra e alcançar os mercados. Isso não implica dizer que eram esses os únicos produtos cultivados no maciço [...] Mesmo nas propriedades das encostas havia uma produção destinada à alimentação dos produtores e de animais eventualmente criados nas propriedades, como aves e burros. No caso de haver um pequeno estábulo, os excrementos dos animais eram aproveitados pelos lavradores para adubar a terra e incrementar o solo, proporcionando uma melhor lavoura.

Como nos demais maciços litorâneos da cidade do Rio de Janeiro, as vertentes do maciço da Pedra Branca eram ocupadas segundo a influência da orientação do relevo, pela declividade da encosta e pelo grau de insolação. Tanto Galvão (1957) e Bernardes (apud Freitas et.al., 2005) citam que a orientação das encostas de soalheira (vertente norte e algumas áreas da oeste), favoreciam ter cultivos de laranja, mamão e mandioca (culturas mais resistentes a falta de umidade e a maior insolação), enquanto que as vertentes de orientação leste e sul, denominadas Noruega, abrigavam cultivos de banana que até hoje são fartos no maciço, principalmente no Vale do Pau da Fome, Camorim, Piabas, até a Serra de Grumari.

Bernardes apud Freitas et.al. (2005) também cita os processos erosivos devido às técnicas de cultivo dos lavradores serem "bastante rudimentares" e não haver conhecimento sobre os efeitos de erosão decorrentes dessa técnica.

Fica claro, portanto, que o processo histórico de ocupação e uso do solo levou a uma fragmentação da área florestal do maciço da Pedra Branca, alterando significativamente a fisionomia e o mosaico da paisagem vegetal atual, hoje, mais constituída de áreas de pastagem e desmatada, aliada aos cultivos de banana que predominam nas porções sudoeste e sudeste do maciço. Isto ocorre devido ao fato da introdução da pecuária extensiva sobre as áreas desmatadas que encontra maior facilidade para se estabelecer.

Atualmente, ainda é possível observar a existência de pequenos sitiantes com sua produção (agricultura de subsistência ou áreas de pastagem de gado e cavalo) nas encostas do maciço da Pedra Branca (Figura 2), fazendo uso intensivo das trilhas e caminhos, transitando nelas com burros e cavalos de tração.

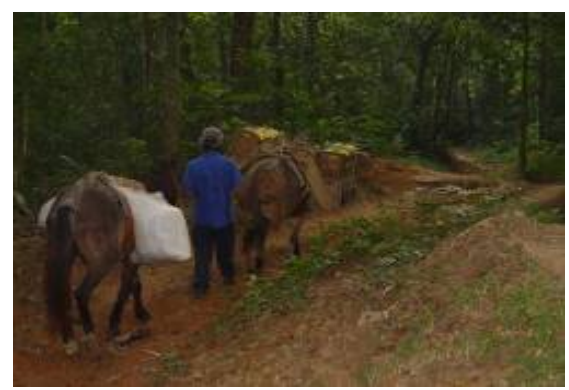

Figura 2: Produtor agrícola transportando banana ao longo da Trilha do Quilombo (PEPB). Foto: Vivian Costa, 2006. 
Após a caracterização geral, abrangendo o maciço da Pedra Branca onde o PEPB está inserido, se faz agora necessário reduzir a escala de trabalho para se compreender melhor a dinâmica da área de estudo e assim entender como os processos erosivos se estabelecem na trilha do Quilombo.

Trilha do Quilombo: outrora um refúgio de quilombolas e recente "paraíso da banana", mas com potencial para o Ecoturismo

A trilha do Quilombo está inserida na vertente leste do maciço da Pedra Branca (Figura 3), próximo à sede do Parque (Figura 4), no final da Estrada do Pau da Fome - Taquara e as comunidades Pau da Fome e Chácara do Céu. Atravessa a bacia hidrográfica do rio Grande, a maior do PEPB, com quase $14 \mathrm{~km}^{2}$ de área.

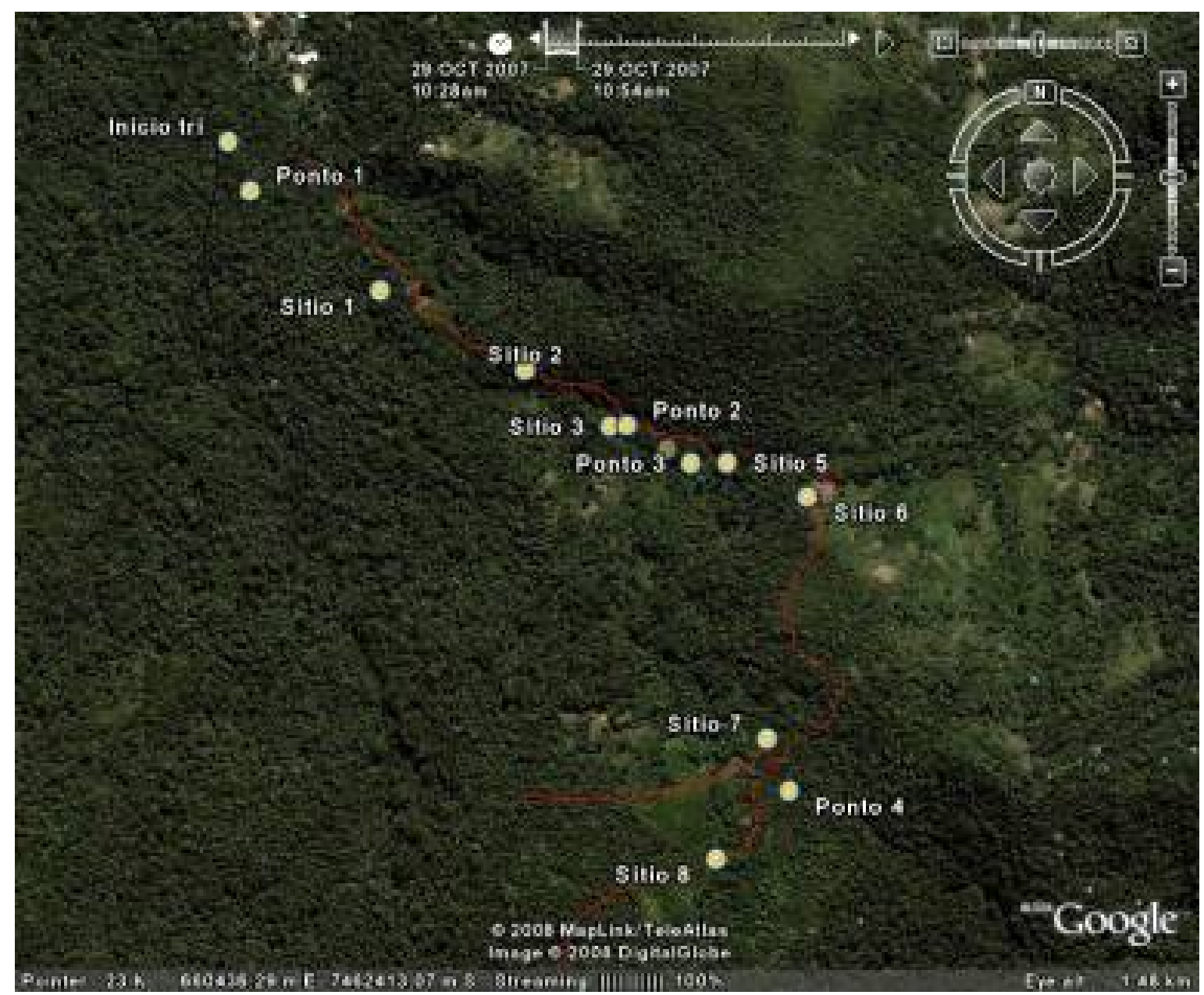

Figura 3: Localização dos sítios e pontos (parcelas) avaliados na trilha do Quilombo (PEPB). Fonte: Google Earth, pontos coletados com GPS em 29 de outubro de 2007 e importados através do software GPS Track Maker. Elaborado por: Beatriz Triane (jan., 2008). 


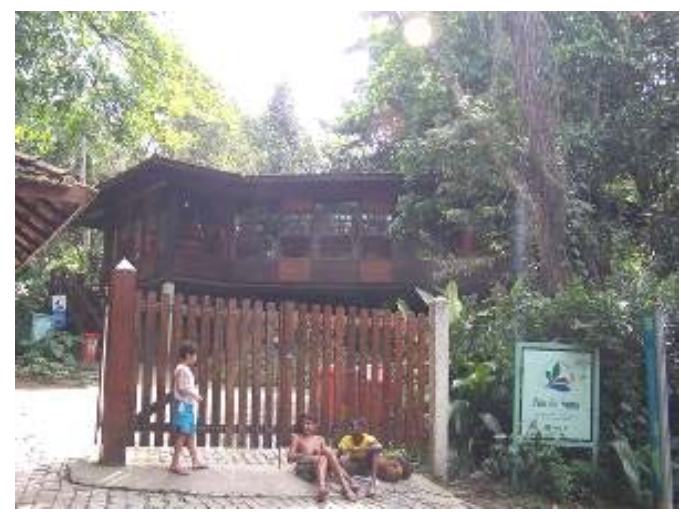

Figura 4: Entrada principal da sede do PEPB (Estrada do Pau da Fome). Foto: Beatriz Triane (2007).

A trilha do Quilombo possui 3,1 metros de extensão, com nível médio de dificuldade e tempo de percurso em torno de 1 hora e 40 minutos, considerando como ponto final a Pedra do Quilombo (Figura 5). Cabe ressaltar que o presente trabalho, procurou avaliar até a extensão de 2.123 metros da trilha (onde havia a presença do último sítio no local), uma vez que se teve por principal objetivo analisar o impacto erosivo no solo causado pelo uso de eqüinos dos sitiantes até esta área.

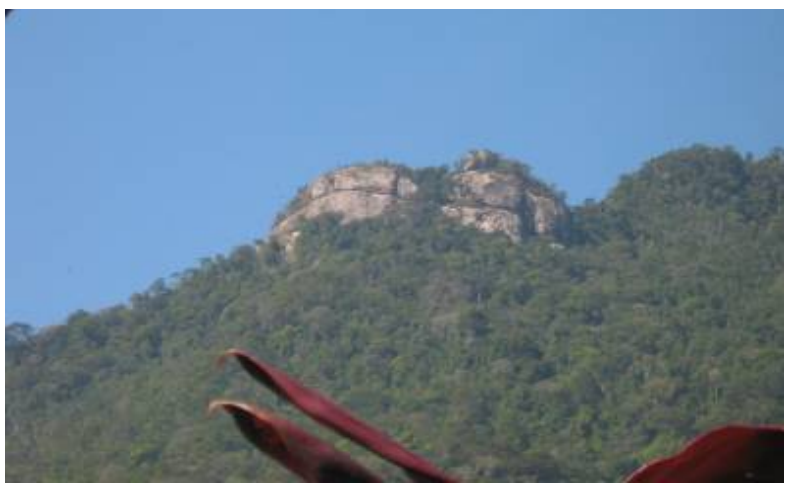

Figura 5: Pico da Pedra do Quilombo a 767 m de altitude.

Foto: Beatriz Triane, 2007.

A história da Trilha do Quilombo é rica e remonta à época da colonização do Brasil. O Engenho do Rio Grande, depois Fazenda do Pau-da-Fome, que se localizava ao pé das serras da Pedra Branca, Barata, Santa Bárbara, Nogueira e Quilombo, pertencia à sesmaria concedida a Antônio de S. Payo (Sampaio) pelo Governador Pedro de Mello em 15 de dezembro de 1665. No século XVIII, estava com Manoel Sampaio, em 1789, com Vasco Ferreira Rangel de Sampaio e, em 1803, com os herdeiros de Miguel de Sampaio (um deles denominava-se João Pimenta) que o venderam ao Comendador Pinto da Fonseca.

No século XIX, em aproximadamente $8,5 \mathrm{~km}^{2}$ da bacia do Rio Grande, foram plantados cafezais. Em 1908 o ministro Lauro Muller desapropriou as vertentes, com 
5,1 $\mathrm{km}^{2}$, ao Barão da Taquara. Dois sítios desta fazenda foram vendidos pela Baronesa de Taquara; um em 1919 a Vicenza Mascone (repassado a Horácio de Oliveira Alves que vendeu em 1924 a Alvino Martim Villas Boas que o transacionou em 1937 com Hermínio Batista de Ornelas) e o outro em 1922 a Antônio Graça Rodrigues Lobo D'Arrochella. O último dono de uma parte das terras do engenho, onde se localiza atualmente o Condomínio Passaredo, foi Francis Hime, pai do compositor, que se dedicava à criação de cavalos. Nessa mesma propriedade, próxima ao entroncamento da atual Avenida dos Mananciais com a Estrada do Rio Grande encontra-se a favela de São Sebastião e nas estradas Curumau e Rio Grande, a favela Jardim Shangri-lá, com $0,6 \mathrm{~km}^{2}$, constituída a partir de um loteamento.

Ainda com relação aos escravos, em Jacarepaguá foi descoberto em 1880 um quilombo nas terras de Camorim, dos beneditinos. Nessa época, a zona oeste apresentou aumento de população com variação significativa nas áreas de maior concentração e diversidade de atividades econômicas, além de melhorias nos serviços públicos.

Gomes (1995) aponta que em uma outra fazenda, a de Iguaçu, os padres "fechavam os olhos" para o quilombo ali existente, o que nos sugere a convivência dos beneditinos com os escravos fugidos. Segundo o Inventário Sumário disponível no Arquivo Nacional (na freguesia de Campo Grande), um dado a ser apontado refere-se à alforria de 68 escravos ocorrida na freguesia de Jacarepaguá, entre janeiro de 1860 e dezembro de 1869, demonstrando que a região da Trilha do Quilombo foi ocupada por remanescentes de quilombolas.

Devido a falta de estudos científicos sobre a história e características específicas sobre a trilha do Quilombo, o presente trabalho também se baseou nos relatos dos moradores mais antigos para tentar caracterizá-lo, principalmente quanto aos dados históricos.

Desta forma, a trilha do Quilombo foi aberta para fuga e passagem de escravos dos antigos engenhos que existiam na região para um suposto quilombo, e por isso, é denominada como tal. Segundo um recenseamento feito em 1838, a área de Jacarepaguá totalizava 7.302 habitantes, dos quais 4.491 eram escravos. A freguesia era a de maior população escrava no município da corte e a partir desde dados é possível se ter uma idéia do possível número de quilombolas refugiados nas matas. Alguns resquícios histórico-culturais deixados pelos escravos do século XIX ainda são possíveis de se observar como demonstra a Figura 6.

A trilha, possivelmente aberta por escravos, vinha sendo utilizada também para agricultura, criação de animais, além de servir de meio de locomoção. Deste modo, mesmo depois da abolição da escravidão, estas populações ficaram residindo na área que hoje compreende o entorno da trilha do Quilombo. Com o passar dos anos, as propriedades foram passadas por herança aos descendentes dos quilombolas e estes repartiram suas terras e as revenderam a terceiros. 


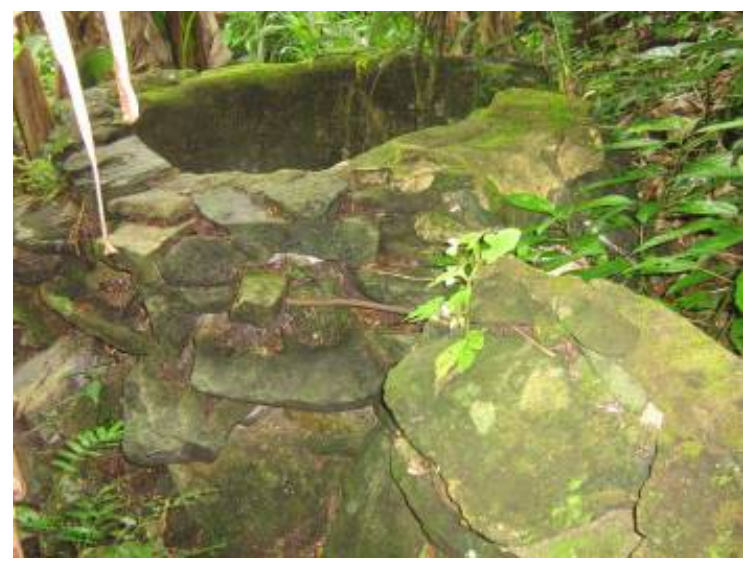

Figura 6: Antigo poço de água (resquício quilombola) existente na trilha do Quilombo. Foto: Beatriz Triane, 2008.

Na trilha, além do patrimônio histórico-cultural presente pelas ruínas e vestígios dos quilombos, em contraste com áreas de florestas (floresta ombrófila densa, mata de encosta e de altitude) encontram-se pontos que apresentam a inserção de cultivos agrícolas de subsistência e/ou de consumo local, em competitividade à recuperação da vegetação. Assim, pontos dispersos, de vegetação degradada com substancial propagação invasora, ficam evidenciados nas transições com os campos e pastagens. Sendo assim, pode-se caracterizar o uso do solo nesta parte do Parque com áreas de cultivo (principalmente banana), de capim/campo (fruto de pastagens e queimadas) e macega, entremeados à floresta (fotos 6, 7 e 8).

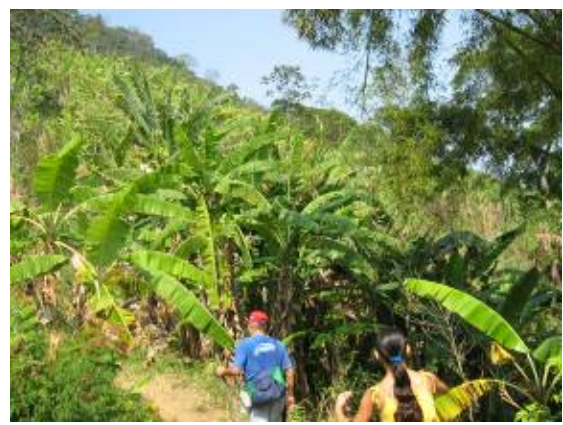

Figura 7

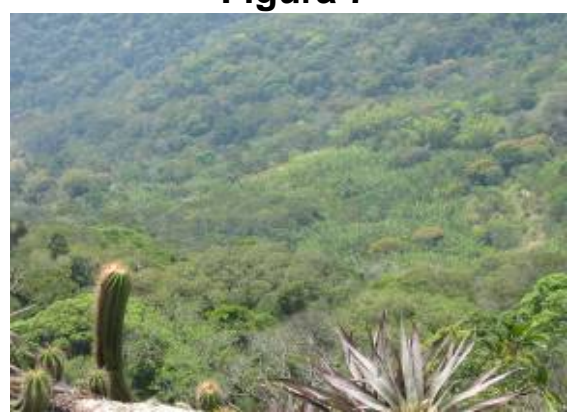

Figura 9

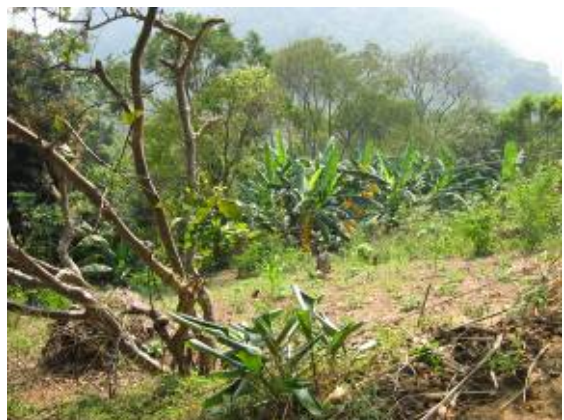

Figura 8

Figura 7: Grande presença de cultivo de banana ao longo da trilha do Quilombo;

Figura 8: presença de áreas sem vegetação (campo e capim) em um trecho da trilha do Quilombo;

Figura 9: Bananais entremeados à vegetação, vista do Pico da Pedra do Quilombo. Fotos: Beatriz Triane, 2007. 
Apesar da grande presença de áreas cultivadas, a trilha do Quilombo apresenta alguns trechos de floresta em estágio médio de regeneração, devido, especialmente as dificuldades de acesso e por isso a cobertura vegetal da região conseguiu estabilizar em espécies típicas de floresta secundária.

Com o passar dos anos, a trilha do Quilombo foi sendo utilizada para passeios ecológicos, principalmente sendo visitada por caminhantes, e desta forma, foi descoberto seu potencial para o turismo de natureza, com a presença de mirantes naturais com belas paisagens, rios e córregos, além de outros atrativos que podem ser aproveitados pelo turismo de aventura ou desportivo como escaladas ao pico da Pedra do Quilombo a 767 metros de altitude com vista privilegiada da baixada de Jacarepaguá, conforme as Figuras 10 e 11.
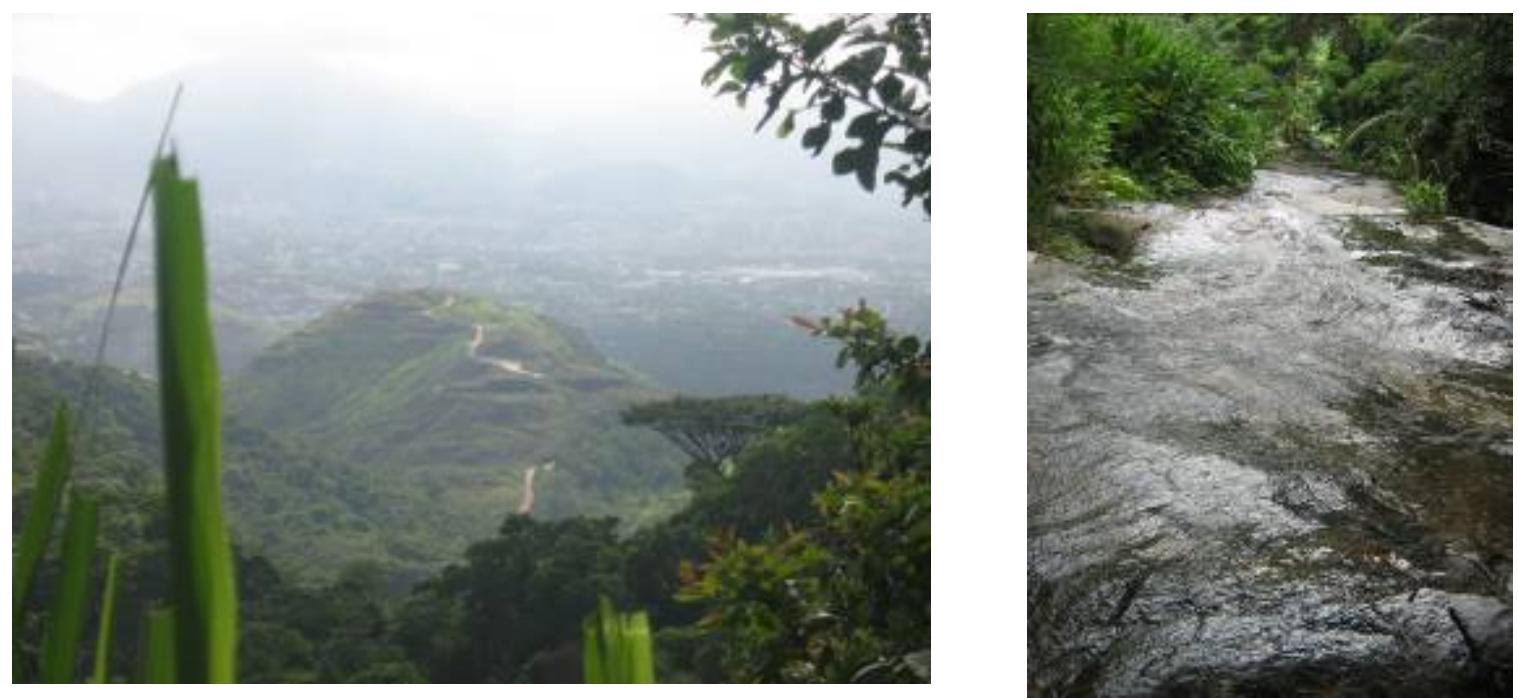

Figura 10 (esquerda): vista de um mirante natural da Trilha do Quilombo.

Figura 11 (direita): atrativos geológicos (formação das rochas graníticas) da trilha do Quilombo que podem ser explorados para atividades de Ecoturismo e turismo geológico.

Fotos: Beatriz Triane, 2007.

\section{Problemas para a visitação na trilha do Quilombo: impactos erosivos}

A trilha do Quilombo carece de manutenção de seu traçado em função de problemas erosivos causados pelo pisoteio de cavalos e mulas, além da falta de controle da drenagem da chuva e de um sistema mais eficaz de sinalização. Vem apresentando problemas também de atalhos e possui bifurcações para a trilha do Rio Grande e para o caminho do Calhariz.

Mas, o que mais vem acelerando os problemas erosivos citados anteriormente são os impactos causados por outras atividades, como a criação de atalhos e caminhos alternativos (Figura 12). Esta trilha vem sofrendo processos erosivos constantes, provavelmente associados a práticas agrícolas (cultura da banana, principalmente) e pecuaristas, além da prática atual do down hill (uso de bicicletas 
Impactos ambientais em trilhas: agricultura X Ecoturismo - um estudo de caso na Trilha do Quilombo

apropriadas para descida em velocidade em trilhas de montanha), como pode ser observado na Figura 13. Apesar disso, seus atrativos naturais são significativos e seu uso, por parte da população local, é crescente, servindo ainda de passagem entre as comunidades residentes em seu entorno.

No entanto, a trilha do Quilombo e a área onde está inserida não sofrem apenas com os impactos provocados pelo uso de animais de carga e bicicletas, mas também a vertente é constantemente assolada por queimadas, muitas vezes provocada por queda de balões (COSTA, 2006a).

Em um relatório sobre um incêndio florestal ocorrido na Pedra do Quilombo em junho de $2005^{2}$, foi detectado grande prejuízo ambiental até a cota altimétrica de 700 $\mathrm{m}$, queimando parte do cume oeste e o seu cume leste inteiramente. De acordo com este documento, o fogo atingiu espécies comuns e espécies típicas da Floresta Ombrófila Montana, o que reduziu a sua biodiversidade e também, um empobrecimento do solo, uma vez que a cobertura vegetal consumida pelo fogo se regenera rapidamente, porém não com as mesmas características primárias anteriores.

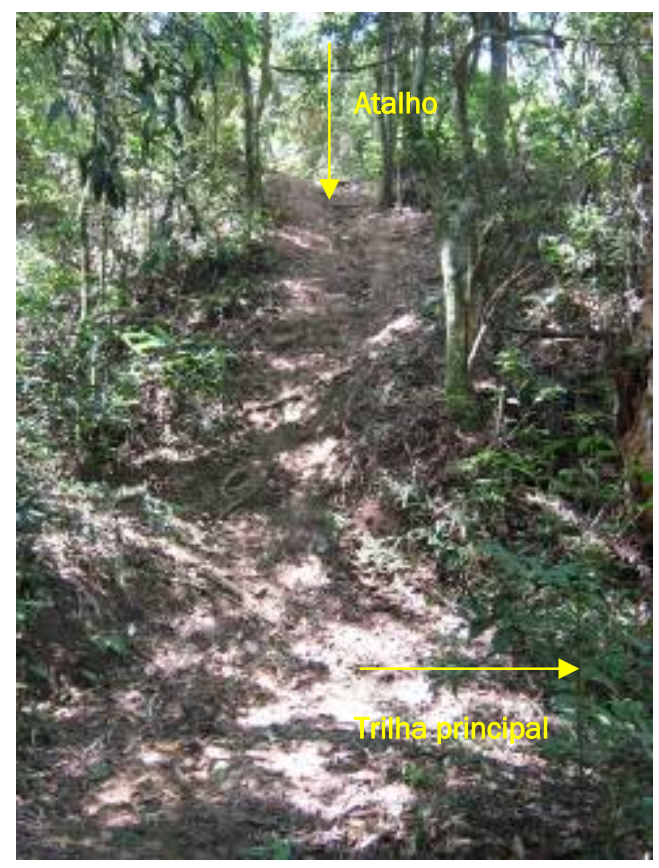

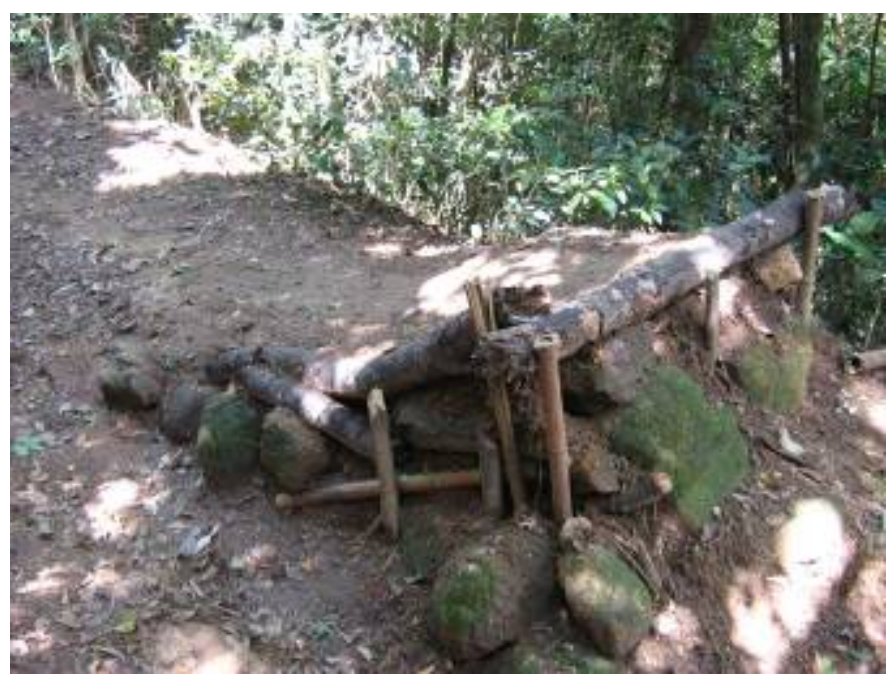

Figura 12 (esquerda): presença de atalho na trilha principal e Figura 13 (direita): rampa feita por praticantes de down hill na trilha do Quilombo. Fotos: Beatriz Triane, 2007.

Mesmo com o seu potencial ecoturístico, a trilha ainda é muito utilizada para escoar a produção dos pequenos sitiantes existentes em seu entorno. E, com isso, tais atividades vêm de certa forma comprometendo alguns trechos da trilha, que demonstram visivelmente um nível considerável de compactação do solo, em função do pisoteio, por décadas, desses animais. Isso implica em sério risco de acidentes aos caminhantes e aumento de problemas erosivos, como os citados no trabalho de Freitas, et.al. (2005). 
Com mais de 30 anos de existência, desde sua lei de criação, o Parque Estadual da Pedra Branca não teve ainda sua situação fundiária regularizada nem tampouco foi elaborado o seu Plano de Manejo, bases para seus programas de gerenciamento e zoneamento. Na prática, ela é mais uma, das várias Unidades de Conservação do país, existentes apenas no papel (COSTA, 2006a).

Essa situação fundiária não só se agrava com a presença de comunidades (favelas, loteamentos irregulares, condomínios fechados, entre outras ocupações urbanas), como também com a presença de sítios, fazendas e pequenas propriedades rurais.

Portanto, o PEPB enfrenta problemas a cerca de sua questão fundiária e fica evidente o real conflito que se estabelece ao se observar a presença de pequenas propriedades agrícolas no interior das Unidades de Conservação. Estas se caracterizam como agricultura familiar ${ }^{3}$ pelo pequeno tamanho de seus terrenos e pelo tipo e volume da plantação (diferente da produção em alta escala). Estas pequenas propriedades agrícolas estão ligadas à exploração através da agricultura de subsistência, cuja produção está direcionada a distribuição no comércio local (pequenos mercados, armazens, feiras, quermesses etc.), principalmente nos bairros próximos do entorno do Parque (zona oeste do município do Rio de Janeiro). É o caso da produção das propriedades agrícolas que se encontram ao longo da Trilha do Quilombo, cuja produção irá abastecer o comércio de bairros próximos como a Taquara e Jacarepaguá.

\section{Como realizar o manejo de impactos em trilhas equestres?}

A gestão de trilhas busca equilibrar a relação entre a satisfação da necessidade de seu uso e a degradação do ambiente, principalmente quando estão inseridas em uma Unidade de Conservação, uma vez que o seu papel é assegurar a proteção e a conservação da natureza.

Para tanto, é fundamental na tentativa de minimizar os impactos e harmonizar a reintegração do homem à natureza, que estudiosos, juntamente com profissionais da área, transformem a abertura de trilhas em um trabalho científico, pedagógico e paisagístico, onde estas possuem diferentes formas, comprimentos, larguras, sinalizações e recursos interpretativos, viabilizando assim o seu usufruto e aproveitando plenamente todo o seu potencial recreativo e educativo, além de elevar o nível de conforto e segurança dos seus usuários.

Sendo assim, na busca de soluções para os conflitos advindos da intervenção humana em espaços naturais, é possível destacar o planejamento e manejo dos espaços físicos e atividades humanas como uma forma de minimizar a influência gerada na dinâmica dos processos naturais.

O planejamento ambiental em Unidades de Conservação requer estudos 
Impactos ambientais em trilhas: agricultura X Ecoturismo - um estudo de caso na Trilha do Quilombo

capazes de estabelecer práticas de manejo que atendam às necessidades de conservação ambiental que, concomitantemente, se adaptem à dinâmica das necessidades dos visitantes e às atividades turísticas, como o uso de trilhas.

Um dos principais pesquisadores estrangeiros que estudam os impactos físicos em trilhas, Cole (1985; 1987), analisou as alterações no solo e na vegetação das trilhas provocadas pelos impactos provenientes do pisoteio de pedestres $\mathrm{e}$ comparando-os com os causados pelas bicicletas.

Alguns autores como Simmons e Cessaford (1989) estudaram o grau dos impactos devido ao uso de bicicletas em diferentes tipos e condições de solo. Entretanto, outros pesquisadores como Wilson e Seney (1994), associam a perda de solo das trilhas com a intensidade da chuva, a declividade e a propriedade do solo, afirmando que estes fatores é que irão determinar a resistência à erosão. Para estes autores os impactos dependem mais de processos geomorfológicos (características físicas e bióticas da área) do que propriamente dos tipos de atividades realizadas nas trilhas.

No Brasil, algumas pesquisas desta natureza já estão sendo realizadas, como os estudos em trilhas da Floresta da Tijuca no Rio de Janeiro, desenvolvidas pelo laboratório GEOHECO-UFRJ (2000) que analisou os impactos em trilhas provocados pelo uso de bicicleta. Tal estudo mostrou o quanto o turismo desportivo acarreta impactos físicos negativos nas trilhas, utilizando cálculos que mensuram a perda de solo.

As trilhas utilizadas por eqüestres em Unidades de Conservação demandam também um manejo mais adequado para prováveis impactos. Segundo Adkison \& Jackson (1996), nessas trilhas podem ocorrer alterações na vegetação e nos microorganismos. Kuss et.al. (1990) afirma que essas alterações influenciam na composição das espécies e na diversidade florística, alem da propriedade e estabilidade do solo. De acordo ainda com este autor, os desvios e atalhos provocados pelos animais representam um dos aspectos negativos e que, no entanto, não recebe a devida atenção.

Os impactos em trilhas, nos últimos anos, são alvos de diversas pesquisas e estudos científicos, e associados a outros conhecimentos sobre elas se tornam importante instrumento para o gerenciamento de áreas protegidas, principalmente quando utilizados na minimização dos impactos negativos.

A principal causa da compactação do solo, segundo Passioura e Gardner (1990), é a ação das forças externas advindas, principalmente, do movimento de máquinas e do trânsito de pessoas e de animais em trilhas. Segundo Cole (1993), o pisoteio pode esmagar, machucar, remover ou expor as raízes das plantas. No solo, o pisoteio altera os seus componentes, como o material mineral, a água, o ar, a matéria orgânica e os organismos vivos.

Quando ocorre o pisoteio na superfície do solo, seja por pessoas, animais ou pela passagem de alguma espécie de veículo, a compactação gera a redução do 
volume de poros disponível para a circulação do ar (redução na aeração) e reduz a movimentação da água dificultando o crescimento e penetração das raízes (COLE, 1993).

Muitos estudos sobre pisoteio de animais e sua influencia no solo relacionam a pressão exercida pelos animais no solo de pastagens e, geralmente, estão vinculadas as questões agronômicas e econômicas. No entanto, existem autores como Hammitt e Cole (1987), Nagy e Scotter (1974), Weaver e Dale (1978) e Whittaker (1978), que observaram a interferência no solo de trilhas em ambientes naturais pelo uso, principalmente do cavalo.

Para Widner e Marion (1993) os impactos do uso do cavalo podem ser ecológicos (impactos ao recurso natural) e/ou social (impactos às experiências de outros visitantes, gerando um conflito de uso da trilha). De acordo com esses autores, ambos os tipos de impacto devem ser tratados com atenção pelos administradores das áreas protegidas.

Ainda de acordo com as idéias de Widner e Marion (1993), a fim de compreender inteiramente os impactos do cavalo e para se chegar às soluções viáveis a respeito de seu manejo, é importante examinar os impactos e os fatores que os influenciam.

Os principais impactos ecológicos que ocorrem em trilhas com o uso do cavalo são: erosão, áreas enlameadas/encharcadas e desenvolvimento incorreto ou aumento da trilha. A erosão é considerada como a forma mais severa de impacto porque seus efeitos são de longa duração, se não permanentes (HAMMIT; COLE, 1987).

A erosão gera trilhas difíceis ou mesmo perigosas de se atravessar e pode criar problemas de assoreamento em rios e em corpos d'água. A erosão do solo resultante do uso do cavalo é um produto do pisoteio, da perda eventual da cobertura vegetal, da compactação do solo, que conduzem à baixa taxa de infiltração de água, desagregação e remoção das partículas da superfície do solo.

Muitos estudos demonstram que o pisoteio por um cavalo é mais destrutivo à vegetação que o pisoteio do caminhante (NAGY; SCOTTER, 1974; WEAVER; DALE, 1978; WHITTAKER, 1978). Um estudo experimental feito por Nagy e Scotter (1974) encontrou uma perda de vegetação quatro a oito vezes maior pelo pisoteio do cavalo do que pelo caminhante. Segundo Hendee et.al. (1990), o peso do cavalo pode exercer uma pressão de $680 \mathrm{~kg}$ por polegada quadrada, aproximadamente.

O tráfego do cavalo pode causar compactação significativa às camadas subsuperficial do solo, reduzindo assim, a infiltração da água e aumentando o escoamento superficial, além da ferradura causar grande remoção do solo (MCQUAID-COOK, 1978). Em um estudo que compara os impactos da erosão em trilhas de caminhantes, cavalos, bicicletas e motocicletas, os desprendimentos dos sedimentos nas trilhas de cavalo eram maiores do que em qualquer outro tipo de uso (SENEY; WILSON, 1991).

O mesmo processo que conduz à erosão pode resultar na formação de áreas 
Impactos ambientais em trilhas: agricultura X Ecoturismo - um estudo de caso na Trilha do Quilombo

enlameadas. Whittaker (1978) observou que a perda do solo pode ser um precursor às seções enlameadas da trilha. O solo desprendido é mais propicio a formar lama do que o solo comprimido e os solos subsuperficiais altamente impactados, devido a pouca infiltração da água, dificultando o percurso e, frequentemente, tem por resultado o alargamento significativo da largura (corredor) da trilha, visto que os usuários utilizam as bordas das áreas enlameadas como alternativa de passagem.

Outro problema das trilhas atribuído ao uso do cavalo é a proliferação de trilhas informais ou secundárias (HAMMITT; COLE, 1987). Além disso, as trilhas criadas por usuários (os chamados atalhos) freqüentemente são mal distribuídas e cuidadas, resultando em uma maior susceptibilidade a degradação da vegetação e potencializando a erosão do solo.

Os estudos feitos em trilhas avaliaram também um número de atributos ambientais que influenciam fortemente a extensão de impactos do cavalo. Para McQuaid-Cook (1986) os impactos encontrados nas trilhas são resultados, principalmente, do declive e da localização da trilha do que um resultado do tipo de usuário. Nagy e Scotter (1974) concluíram que, embora o uso do cavalo geralmente provoque mais danos do que os caminhantes, o grau de diferença no impacto depende do solo, do tipo da vegetação, do clima (mais chuvoso ou não) e das características topográficas da trilha utilizada.

\section{Quais são e como resolver os impactos erosivos na trilha do Quilombo?}

Na trilha do Quilombo, é possível compreender, através do estudo, que esta apresenta impactos relacionados à passagem contínua de animais de carga sem o devido manejo do local. Ressalta-se que um estudo mais aprofundado dos processos erosivos deverá ser feito compreendendo um trabalho laboratorial que permita analisar as propriedades físicas (textura e estrutura) e químicas do solo que influenciam estes processos.

De acordo com entrevistas informais a moradores e a fiscalização (administração) do PEPB, as práticas de manejo se resumem, na maioria das vezes à limpeza dos caminhos. Foram poucas as vezes que melhorias, tais como: abertura e limpeza de canais de drenagem foram citadas. Em recente trabalho de campo realizado (28/01/2008), foi possível observar uma árvore caída na trilha, onde os próprios moradores abriram uma trilha alternativa para contornar esse "obstáculo" (Figuras 14 e 15). 

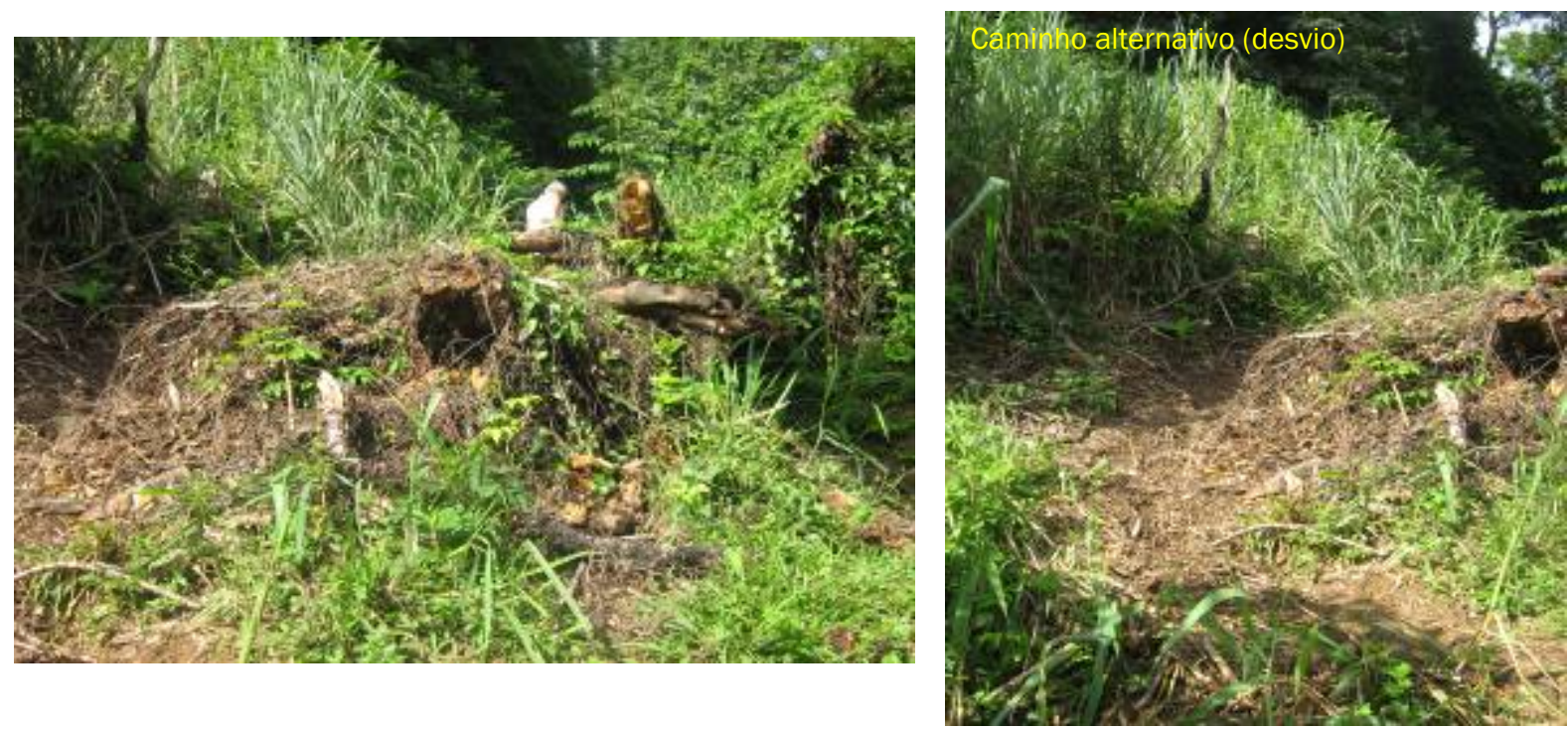

Figura 14 (esquerda): Árvore caída na trilha do Quilombo.

Figura 15 (direita): Caminho aberto como desvio no trecho com a árvore caída.

Fotos: Beatriz Triane, 2008.

O pisoteio sucessivo também se caracteriza como um dos principais responsáveis pelo impacto na estrutura do solo $\mathrm{e}$, conseqüente aumento de sua susceptibilidade à erosão. Os pisoteio dos animais de carga, principalmente eqüinos, funcionam como elemento concentrador de água no leito da trilha, desencadeando assim, processos sucessivos de sulcos e ravinamentos.

O principal problema observado na trilha do Quilombo consiste na formação do sulco provocado pelo escoamento superficial difuso e pelo efeito do splash (impacto da gota de chuva no solo) que acaba por criar no solo condições favoráveis para a erosão laminar e o aumento do processo erosivo. Intensificado pela declividade ou pela presença de solo argiloso, a erosão evolui para o ravinamento, tendo na concentração de água de enxurrada o seu ponto de início.

Nos trechos (entre os pontos amostrais de observação - ponto 1 ao ponto 3) da trilha do Quilombo após alguns dias de chuvas de verão (27/01/2008) foi possível perceber claramente no solo, influencias do pisoteio de animais (Figuras 16 e 17) e a concentração de água e materiais transportados (Figuras 18 e 19) que, associados ao tipo de solo argiloso e compactado, favorecem a formação de grandes áreas com lama, dificultando caminhar por esses trechos e a perda de solo na trilha. 


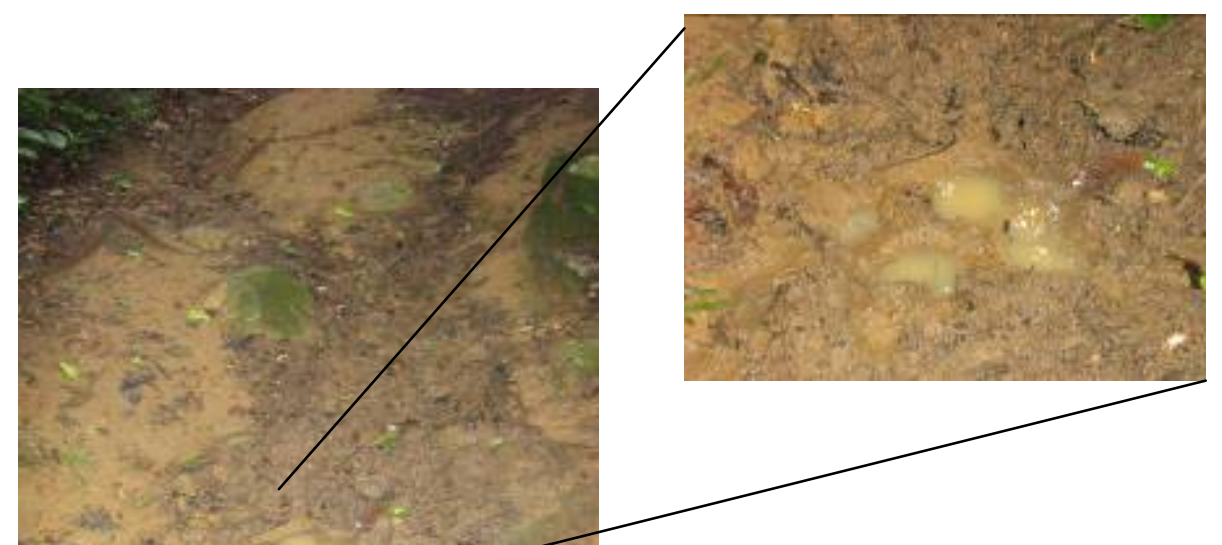

Figura 16 (esquerda): trecho enlameado no leito da trilha do Quilombo.

Figura 17 (direita): marcas do pisoteio de cavalo (ferradura) no solo. Fotos: Beatriz Triane, 2008.

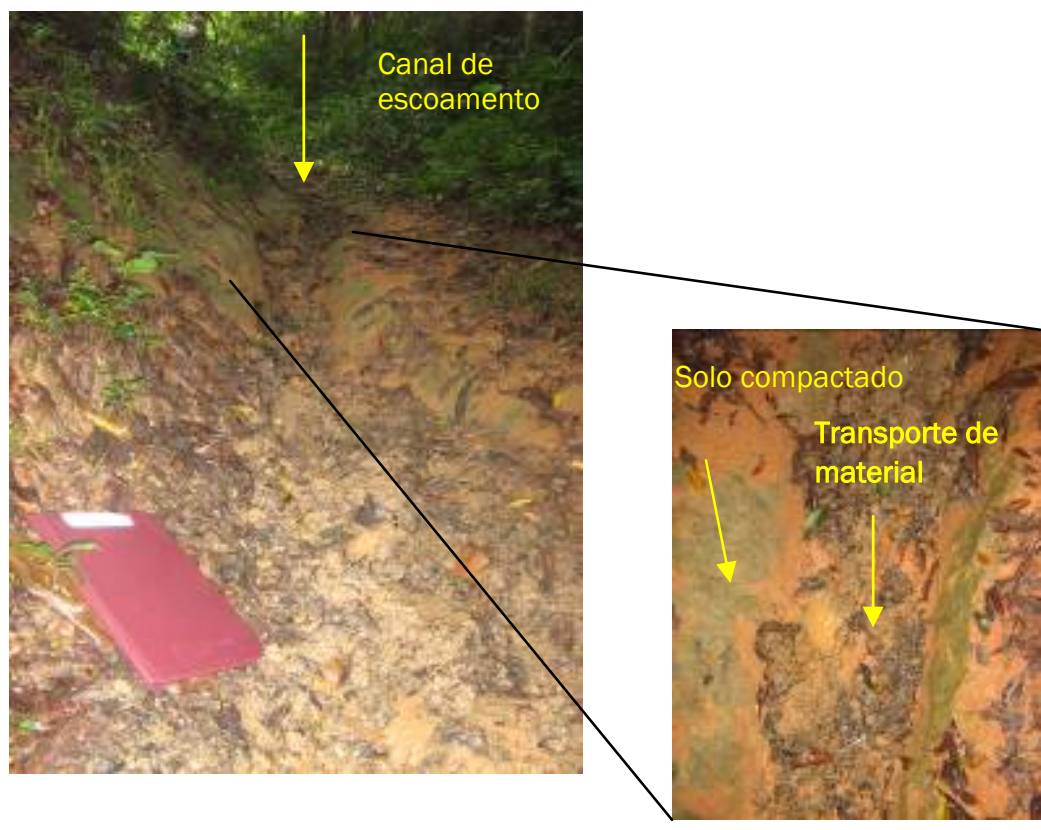

Figura 18 (esquerda): canal de escoamento superficial da água em um trecho da trilha do Quilombo.

Figura 19 (direita): compactação do solo de um trecho da trilha do Quilombo, formação de canal de escoamento superficial e transporte de material (sedimentos e material orgânico) no leito da trilha.

Fotos: Beatriz Triane, 2008.

Settergren e Cole (1970), observaram as diferenças nas características do solo resultantes da pressão do uso, definindo certas limitações para o crescimento e desenvolvimento normal da vegetação. Dentre as diferenças encontradas, as mais significativas foram a compactação do solo e a destruição da cobertura da vegetação que protege a superfície do mesmo. Neste sentido, a compactação do solo reduz o poder de infiltração da água e também aumenta os efeitos da enxurrada, daí a perda do solo (lixiviação) em vários trechos da trilha do Quilombo, como foi mencionado anteriormente. 
Em suma, em uma trilha, para o bom escoamento superficial deve ser levada em consideração a "declividade da drenagem" (calha de escoamento superficial) de forma com que a drenagem da água pluvial atravesse transversalmente e naturalmente à trilha. Desta forma o modo de se conseguir isto é seguir "uma rota que naturalmente acompanhe a topografia do terreno (curvas de nível), estudando seus componentes e suas variações bio-físicas" (COSTA, 2006a, p.154) e não criar caminhos alternativos como vemos ocorrer na trilha do Quilombo, fazendo aumentar os efeitos negativos de seus impactos erosivos (Figuras 20 e 21).

A presença de impactos negativos em trilhas, tanto no solo, quanto na vegetação, na fauna ou na água, são conseqüências inevitáveis do uso público. No entanto, esses impactos podem ser minimizados através da implementação de estratégias de manejo e monitoramento, tais como:

- Sistema de trilha eficiente, com a implantação de estruturas como escadas, canais de drenagem, barreiras de desvio d'água, passarelas e pontes;

- Programa de manutenção e monitoramento das intervenções realizadas nas trilhas;

- Sistema de sinalização eficiente, principalmente quanto a prevenção de erosão;

- Programa de monitoramento dos impactos (físicos e sociais);

- Capacitação de fiscais, grupos de voluntários, agricultores, entre outros atores sociais, através de mini-cursos, para uma conduta mais consciente sobre a intervenção e conservação de trilhas nas áreas naturais protegidas, baseados nos princípios de mínimo impacto.

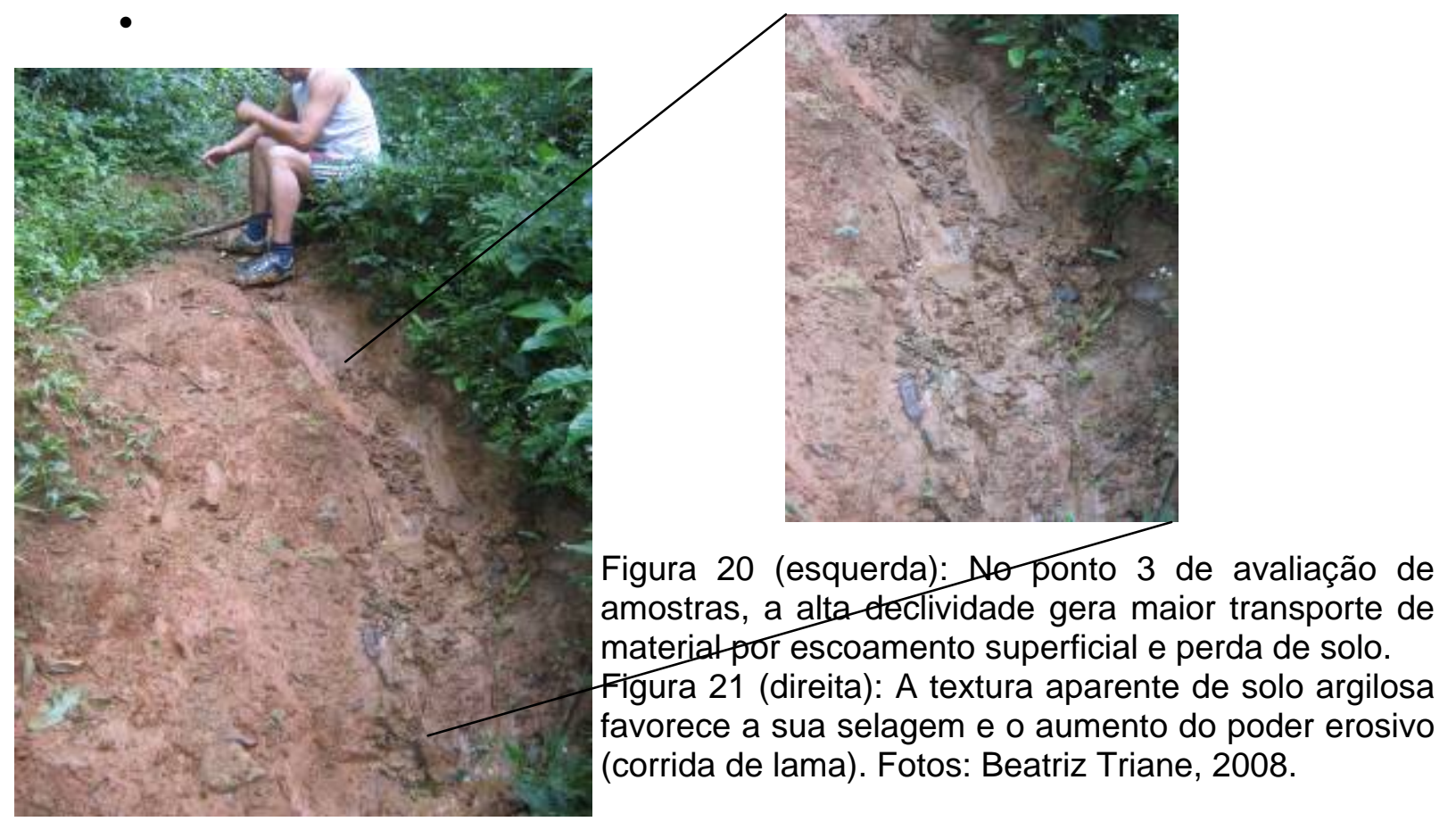


Impactos ambientais em trilhas: agricultura X Ecoturismo - um estudo de caso na Trilha do Quilombo

Existem várias ações a serem realizadas, mas a mais importante talvez seja a criação de parcerias entre pesquisadores (academia), ONGs, órgãos públicos e a administração de Unidades de Conservação. Estas parcerias podem criar alternativas viáveis e efetivas para a utilização desta importante via que é a trilha, visto, sua importância como veículo de conscientização sobre a preservação da Mata Atlântica e como esta precisa ser usada de forma sustentável, criando alternativas, seja através do Ecoturismo, como do turismo cultural, a exemplo do potencial da trilha do Quilombo que não é bem aproveitado pelos gestores do Parque Estadual da Pedra Branca.

O termo "indicadores de impacto", empregado no presente estudo, significou a análise dos indicadores associados aos impactos provenientes dos processos erosivos que ocorrem em trilhas, os quais podem ser monitorados e analisados de maneira eficiente através de métodos não só quantitativos, mas qualitativos (FREIXÊDAS-VIEIRA et.al., 2000). Um conjunto de indicadores de impactos é um painel de análise de uma dada situação, portanto, buscou-se, com o resultado da análise, apontar para indicadores que mostrassem a situação específica de determinado aspecto erosivo na trilha e que servisse de parâmetro para a realização de estimativas acerca da situação de outros impactos não estudados.

Os pontos mais impactados na trilha, ou seja, que apresentaram uma maior perda de solo (área transversal) e maior compactação foram: o ponto 1A e o ponto 3. Dentre os parâmetros e indicadores de impactos utilizados, pode-se dizer que a declividade foi o que melhor esclareceu o resultado encontrado, na medida que os pontos $1 \mathrm{~A}$ e 3 , possuem declividade acima de $25 \%$.

A alta declividade de alguns trechos da trilha estudada, aliada a um solo com textura argilosa favorece a erosão superficial que resulta na perda de solo. A compactação desta parte superficial, resultante do pisoteio é outro fator que dificulta a recuperação do leito. A partir da análise deste parâmetro pôde-se observar como a trilha funcionava, pois a formação de canais de drenagem como concentrador e escoadouro da água da chuva foi o principal facilitador do escoamento superficial, apoiado pela compactação do solo.

Sendo assim, o desvio da enxurrada através da construção de pequenos canais dissipadores de energia se constitui em uma das principais recomendações para o manejo adequado, em curto prazo, principalmente para os pontos 2 e 3 que possuem maior problema de concentração de drenagem por canais formados pela chuva.

A identificação e avaliação dos parâmetros físicos como determinantes do impacto decorrentes do uso (pisoteio de animais) em trilhas, através de métodos eficientes, devem ser considerados como formas eficazes para reconhecer problemas erosivos em trilhas. A profundidade do leito da trilha e a dificuldade para caminhar, devem representar muito mais que simples aventura e emoção para os visitantes em um parque. Na verdade, devem ser analisados como reflexos de um manejo ineficiente e representam um risco potencial para os visitantes. 
Desta maneira, além de relacionar parâmetros físicos indicadores do grau de impacto, para evitar problemas semelhantes no planejamento de novas áreas de uso público, devem ser listados também os problemas relacionados ao manejo dos recursos, sob o ponto de vista institucional. São estes fatores, na verdade que determinam a aplicação ou não de técnicas adequadas de planejamento e manejo.

Trabalhos de monitoramento posteriores que venham a utilizar a metodologia empregada nesta pesquisa deverão observar os seguintes pontos:

- Aumentar o número de unidades amostrais de monitoramento;

- Medir a profundidade máxima de cada área transversal;

- Analisar as propriedades físicas e químicas do solo em laboratório.

Este monitoramento deverá ter o intervalo entre os levantamentos, aproximadamente, a cada cinco anos, para se detectar mudanças significativas entre os parâmetros avaliados (McEWEN et.al., 1996). Cole (1991) trabalhando com um intervalo de 9 a 11 anos entre as coletas de dados observou diferenças para algumas variáveis, mas as maiores diferenças estiveram relacionadas com a largura total da trilha. A profundidade máxima também aumentou, mas não significativamente. Segundo o autor, em um período de 11 anos quase não houve erosão. Afirmou ainda que a trilha que teve manutenção mínima apresentou um aumento de solo exposto mais significativo que uma das trilhas cuja manutenção foi feita de maneira intensiva. Portanto, isso denota a complexidade e a importância de serem realizadas pesquisas dessa magnitude em trilhas e ainda mais em ambientes diferentes, tanto em áreas subtropicais como em áreas tropicais ou semi-áridas, a fim de serem monitoradas de forma adequada à realidade regional e local.

\section{Novas propostas de manejo dos impactos}

Neste contexto, a partir dos resultados encontrados é de fundamental importância que medidas mitigadoras de impactos possam ser tomadas pelos gestores do PEPB, tendo como uma de suas bases, o diagnóstico realizado neste estudo. Deste modo, para a manutenção da trilha e controle de seus impactos negativos, além de sugestões complementares de manejo. A seguir são apresentadas algumas considerações importantes, baseadas nos resultados obtidos com a pesquisa:

- Incentivo ao Ecoturismo

A trilha do Quilombo possui um grande potencial Ecoturismo que deve ser explorado pelo PEPB com um programa que incentive o uso público da trilha. $\mathrm{O}$ 
Impactos ambientais em trilhas: agricultura X Ecoturismo - um estudo de caso na Trilha do Quilombo

Ecoturismo é uma importante ferramenta para se promover um desenvolvimento sustentável nas áreas de interesse turístico e de recursos naturais importantes, garantindo a sua preservação, além das tradições culturais e oferecendo alternativas para a geração de emprego e renda para a população local. As propostas convergem para o monitoramento contínuo dos trechos de trilhas mais impactados, paralelamente ao controle do uso dos animais de carga, chegando num consenso entre a administração do Parque e os seus sitiantes.

- Realocação dos trechos problemáticos

$\mathrm{Na}$ trilha do Quilombo ocorrem trechos que possuem diferentes estados de conservação. Cole (1991) observou o mesmo no sistema de trilhas em Selway Betterroot (EUA) e afirmou que os fatores que mais influenciam as condições das trilhas são a localização e o planejamento. Deste modo, a principal solução para os problemas nas trilhas envolve o aumento de sua capacidade para suportar o uso (através da melhoria do planejamento e engenharia) ou a mudança da localização da mesma para um local onde seja mais adequado para o uso constante (suportar o peso e o volume de carga). A preocupação com cálculos para a capacidade de carga da trilha do Quilombo também deve ser considerada, pois a avaliação qualitativa pode ser aliada ao número de visitantes ou de passagem da carga de animais (peso $X$ tempo $X$ velocidade). Desta forma, poderiam ser experimentadas novas metodologias para adequar o multiuso da trilha, ou seja, destinar trechos da trilha para só passarem pessoas e outros trechos para passagem de animais de carga, além de trechos mais resistentes a passagem de ambos (com maior poder de absorver os impactos).

Assim, alguns trechos deverão ser abandonados, e novos trechos deverão ser abertos evitando grandes declividades, principalmente em locais onde o solo pode ser mais propício aos processos erosivos. Desta forma, a bifurcação encontrada no primeiro ponto da trilha deverá ser melhor estudada a fim de se conhecer o melhor caminho a ser utilizado. O trecho com maior perda de solo (ponto 3), deverá ser manejado com a finalidade de se minimizar os efeitos dos processos ali existentes. A água da enxurrada deve ser desviada para diminuir a perda do solo e a recuperação da vegetação deve ser auxiliada através do plantio com mudas retiradas das imediações ou do horto do PEPB, existente na Colônia Juliano Moreira (Jacarepaguá).

- Recuperação da trilha e de suas bifurcações

Algumas ações visando a recuperação da trilha principal, principalmente no trecho com bifurcação, incluem o reflorestamento, através, por exemplo, da escarificação do solo, semeadura, fertilização ou transplante. Segundo Cole e Ranz, (1983), a colocação de barreiras ou redes de juta sobre áreas semeadas ou 
transplantadas podem aumentar o sucesso da recuperação e também desencorajar o uso pelos lavradores da região para espécies invasoras. Várias técnicas são citadas por Cole e Schreiner (1981) para aumentar a velocidade de recuperação do solo e da vegetação.

Para que as áreas sejam recuperadas, deverão ser produzidas mudas das espécies existentes no Parque, abrangendo assim, um programa de Educação Ambiental, que pode ser desenvolvido em conjunto com escolas, universidades, diversos órgãos ambientais, voluntários e os próprios agricultores locais. Além de auxiliar na recuperação das áreas afetadas, esta ação poderá contribuir com a formação em atividades de paisagismo, e inclusive permacultura, das pessoas que passarem pelo programa a ser ministrado nas dependências do próprio Parque (a sede administrativa poderá servir, portanto, de área modelo ou piloto para toda a UC).

A trilha do Quilombo está sob a proteção legal das Unidades de Conservação o Parque Estadual da Pedra Branca - e sob as restrições a ela impostas por esta categoria. Apesar disso, ainda é mantida, principalmente, com os mesmos objetivos de décadas atrás, ou seja, utilizada para deslocamento de sitiantes do interior do Parque, para o avanço de ações de degradação ambiental (desmatamentos, queimadas, retirada de palmito, entre outros) e sem restrições de um Plano de Manejo ainda inexistente. $\mathrm{Na}$ realidade, o que foi observado no decorrer do desenvolvimento da presente investigação, é que não ocorreu o efetivo planejamento e muito menos um manejo efetivo, por parte de seus gestores, na implantação e manutenção da trilha do Quilombo e muito menos das trilhas próximas à sede e subsedes do Parque.

\section{Considerações Finais}

De modo geral, os planejadores e gestores das Unidades de Conservação preconizam a proteção do sistema solo-água-vegetação através de diagnósticos detalhados, particularmente sobre a biota (fauna e flora), porém ainda não consideram as trilhas, veículos condutores de conservação do meio ambiente local. Assim sendo, de acordo com Costa (2006a), a área do maciço da Pedra Branca, que comporta a maior área protegida do município do Rio de Janeiro, carece de estudos detalhados sobre as trilhas, tendo como foco de avaliação, a sua vulnerabilidade natural à ocorrência de impactos, sua capacidade de suporte à visitação e suas potencialidades.

O sistema agrícola vigente na área representa um risco para a sustentabilidade do ecossistema. Portanto, a adequada capacitação e orientação dos produtores nas práticas agroecológicas, podem viabilizar a reprodução social e econômica dos sítios no interior e entorno do PEPB e contribuir para políticas de preservação ambiental. 
Impactos ambientais em trilhas: agricultura X Ecoturismo - um estudo de caso na Trilha do Quilombo

Espera-se estender tais ações, não somente para a trilha analisada, mas também, para as outras trilhas e caminhos existentes no PEPB, considerando que estes são o veículo de ação conservacionista e/ou meramente contemplativa da natureza. Visto que no Brasil, os estudos referentes aos impactos causados pelos animais se restringem a áreas de pastoreio e/ou plantações e, dizem respeito em sua maioria da compactação do solo advindo do pisoteio de bovinos. As pesquisas desenvolvidas com esta temática, até o momento não abrangiam as áreas florestadas e protegidas.

Desta forma, a presente pesquisa possui um cunho inovador à medida que aborda os efeitos, principalmente dos eqüinos, sobre o solo no interior de uma Unidade de Conservação. Todavia, a evolução das pesquisas com este tema encontra dificuldade, principalmente, pela falta de teorias especificas e pensamento conceitual.

Este estudo proporcionou um melhor conhecimento e entendimento da trilha do Quilombo e demonstra-se como uma importante ferramenta para o manejo e conservação da área na medida em que se desenvolve a partir de fáceis e práticos métodos.

À medida que o impacto, como visto antes, é decorrente inevitável do uso repetitivo, os gestores de Unidades de Conservação devem decidir sobre os níveis aceitáveis de impacto e, em seguida, executar ações capazes de manter os objetivos estipulados. Tendo em vista que os impactos ocorrem rapidamente, enquanto a recuperação ocorre de forma mais lenta. Isto ressalta a importância do papel da gestão, pois é muito mais fácil evitar o impacto do que restaurar os locais impactados (COLE, 2004). A magnitude do impacto é uma função da freqüência de uso, do tipo de comportamento e forma de utilização, das condições ambientais, bem como a distribuição espacial da utilização. Portanto, a principal ferramenta de gestão envolve manipulação desses fatores.

Deste modo, os acessos principais do parque devem ser monitorados pelos gestores dos PEPB, a fim de se evitar a degradação nas áreas próximas aos caminhos e trilhas, evitando riscos de erosão e movimentos de massa ou mesmo facilitando o acesso de adeptos do turismo de aventura sem controle, tais como, o motocross, raly e montan bike, ampliando ainda mais seus efeitos impactantes. Uma das alternativas de controle do acesso e fluxo de visitantes nas trilhas é a criação de novas sub-sedes no interior da área protegida bem como a implementação de atendimento eficaz e infra-estrutura adequada, aliada aos programas de conscientização do uso público em parques, principalmente como sendo da categoria de proteção integral.

Apesar da prática do Ecoturismo ainda estar abaixo do que é esperado pelos princípios básicos e diretrizes estabelecidos em seus programas, este estudo se propõe como uma contribuição acadêmica, com a finalidade de se tornar mais um instrumento de apoio à conservação ambiental, melhoria da qualidade de vida dos visitante e residentes no interior e na periferia próxima ao Parque, além da sensibilização ecológica. 


\section{Referências}

ADKISON, G. P.; JACKSON, M. T. Changes in Ground-Layer Vegetation Near Trails in Midwestern U.S. Forests. Natural Areas Journal.v 16, 1996. p. 14-23.

ANDRADE, W. J. Manejo de trilhas para o Ecoturismo. R. Mendonça \& Z. Neiman (orgs.). In: Ecoturismo no Brasil. Barueri, SP: Manole, 2005. p. 131-152.

BERNARDES, L. M. C.. Evolução da paisagem urbana do Rio de Janeiro até o início do século XX. In: ABREU, Maurício (Org.) Natureza e sociedade no Rio de Janeiro. Rio de Janeiro: Secretaria Municipal de Cultura, Turismo e Esportes, 1992. p.37-53.

COLE, D. N. Recreational trampling effects on six habitat types in Western Montana. USDA Forest Service. Research Paper INT-350. 1985. 43p.

. Research on soil and vegetation in wilderness: a state-of-knowledge review. In: LUCAS, Robert C., comp. Proceedings-national wilderness research conference: issues, state-ofknowledge, and future directions. 1985 July 23-26; Fort Collins, Co. Gen. Tech. Rep. INT-220. Ogden, UT: U.S. Department of Agriculture, Forest Service, Intermountain Research Station. 1987. p. 135-177.

. Changes on trails in the Selway-Bitterroot Wilderness, Montana, 1978-89. USDA, Forest Service. Intermountain Research Station. Research Paper INT-450. 1991. 5p.

. Minimizing conflict between recreation and nature conservation. In: SMITH, D. S.; HELLMUND, P. C. Ecology of greenways. Minneapolis: University of Minnesota, cap.5, 1993. p.105-122.

. Impacts of hiking and camping on soils and vegetation: a review. In: Buckley, Ralf (ed.) Environmental impacts of ecotourism. CAB International: Wallingford UK. 2004. p. 41-60.

COLE, D. N.; RANZ, B. Temporary campsite closures in the Selway-Bitterroot Wildernes. Journal of Forestry, v.81, 1983. p.729-32.

COLE, D. N.; SCHREINER, G. S. (compilers). Impacts of Backcountry Recreation: Site Management and Rehabilitation - An Annotated Bibliography. USDA Forest Service. Intermountain Forest and Range Exp. Station. General Technical Report INT-121. 1981. 58p.

COSTA, S. M. Contribuição Metodológica ao Estudo da Capacidade de Carga Turística em Áreas Preservadas: o caso da Unidade de Conservação do GericinóMendanha (RJ) 2004. 124 f. Dissertação (Mestrado em Geografia), Programa de PósGraduação em Geografia, Universidade Federal do Rio de Janeiro, R. Janeiro. 2004.

COSTA, V. C. da. Proposta de Manejo e Planejamento Ambiental de Trilhas 
Impactos ambientais em trilhas: agricultura X Ecoturismo - um estudo de caso na Trilha do Quilombo

Ecoturísticas: um Estudo no Maciço da Pedra Branca - Município do Rio de Janeiro (RJ). 2006. 325 f. Tese (Doutorado em Geografia) Instituto de Geociências, Universidade Federal do Rio de Janeiro, Rio de Janeiro. 2006a.

. Planejamento e Manejo de Trilhas. In: I CONGRESSO NACIONAL DE PLANEJAMENTO E MANEJO DE TRILHAS - I CNPMT, 2006, Anais... Rio de Janeiro: UERJ. 2006b.

DALE, P. Definindo Ecoturismo... Para quê? Para quem? In: NEIMAN, Zysman; MENDONÇA, Rita (orgs). Ecoturismo no Brasil. Barueri, SP: Manole, 2005.

FREITAS, M. M.; et.al. A Influência dos Remanescentes Agro-pastoris do maciço da Pedra Branca na dinâmica hidrológica das encostas. In: As Marcas do Homem na Floresta: história ambiental de um trecho urbano de mata atlântica. Oliveira, R. R. de (org.), Rio de Janeiro: Ed. PUC-Rio, 2005. p. 143-166.

FREIXÊDAS-VIEIRA, V. M.; PASSOLD, A. J.; MAGRO, T. C. Impactos do uso público um guia de campo para utilização do método VIM. 2000. In: CONGRESSO BRASILEIRO DE UNIDADES DE CONSERVAÇÃO, Anais... , 2, Campo Grande: Rede Nacional Pró-Unidade de Conservação/Fundação Boticário, 2000, p. 296-305.

GEOHECO-UFRJ (Laboratório de Geo-hidroecologia). Diagnóstico/Prognóstico sobre a Qualidade Ambiental do Geoecossistema do Maciço da Tijuca subsídios à regulamentação da APARU do Alto da Boa Vista. Relatório entregue à Secretaria de Meio Ambiente/PMRJ. Rio de Janeiro, UFRJ. 2000. 154p

GOMES, F.S. Quilombos do Rio de Janeiro. In: Flávio dos Santos Gomes e João José Reis. Liberdade por um fio. História dos quilombos no Brasil. Rio de Janeiro: Companhia das Letras. 1995. 512p.

HAMMITT, W. E.; COLE, D.N. Wildland Recreation: Ecology and Management. 2.ed New York: John Wiley and Sons,. 1987. 361 p.

HAWKINS, D. E.; KAHN, M. Oportunidades para o turismo ecológico nos países em desenvolvimento. In: THEOBALD, W. F. (org). Turismo Global. São Paulo: SENAC, 2001. p.205-218.

HENDEE, J. C., et.al.. Wilderness management. 2. ed.. North American Press, Golden, Colorado, USA. 1990.

KUSS, F. R.; GRAEFE, A. R.; VASKE, J. J.. Visitor impact management: a review of research. Washington, DC: National Parks and Conservation Association. 1990. MACHADO, A. Ecoturismo: Um Produto Viável. A Experiência do Rio Grande do Sul. Rio de Janeiro: SENAC Nacional, 2005. 232 p.

McEWEN, D.; COLE, D. N.; SIMON, M. Campsite impacts in four Wildernesses in the South-Central United States. USDA. Forest Service. Intermountain Research Station. Research Paper INT-RP-490. 1996. 12 p. 
MCQUAID-COOK, J. Effects of hikers and horses on mountain lakes. Journal of Environmental Management. v 6,1978, p. 209-212.

MEIRELLES FILHO, J. O equilíbrio entre a atividade econômica e a sustentabilidade socioambiental. In: MENDONÇA, R.; NEIMAN, Z. O Ecoturismo no Brasil, São Paulo: Manole, p. 131-152. 2005.

NAGY, J. A.; SCOTTER, G. W. A qualitative assessment of the effects of human and horse trampling on natural areas, Waterton Lakes National Park. Canadian Wildlife Service, Edmonton, AB. 1974. 145 p.

PASSIOURA, J. B.; GARDNER, P. A. Control of leaf expansion in wheat seedlings growing in drying soil. Australian Journal of Agricultural Research., v. 17, 1990.

p. 149-157.

SALVATI, S. S. Certificação em Ecoturismo: lições mundiais e recomendações para o Brasil. Brasilia: WWFBrasil, 2001.

SCHELHAS, J. Construção e manutenção de trilhas. In: Curso de Treinamento e Capacitação em Gerenciamento de Parques e outras Áreas Protegidas, São Paulo, 22 nov. a 14 Dez., 1986. São Paulo, Instituto Florestal. v1. (não paginado).

SEABRA, L. Determinação da Capacidade de Carga Turística para a Trilha Principal de Acesso à Cachoeira de Deus, Penedo. Dissertação (Mestrado em Ciência Ambiental) - Universidade Federal Fluminense, Rio de Janeiro, 1999. 177p.

SENEY, J. P.; WILSON, J.P. Erosional impact of hikers, horses, off-road bicycles, and motorcycles. Bozeman, MT: Montana State University, Dept. of Earth Sciences. Final Report to USDA Forest Service, Intermountain Research Station. 1991

SETTERGREN, C. D.; COLE, D. N. Recreation effects on soil and vegetation in the Missouri Ozarks. Journal of Forestry, v 68, no 4, 1970. p. 231-233.

SIMMONS, D. G.; CESSFORD, G. R. The St James Walkway Study. Occasional Paper No.1. Department of Parks, Recreation and Tourism, Lincoln University, Canterbury, New Zealand. 1989.

WHITTAKER, P. L. Comparison of surface impact by hiking and horseback riding in the Great Smoky Mountains National Park. U.S. Department of the interior, National Park Service, Uplands Field Research Laboratory. Final Research Report. 1978,32 p.

WIDNER, C.; MARION J. Horse impacts: research findings and their implications. LNT Master Network, nº.5. 1993.

WILSON, J. P. SENEY, J. P. Erosional impact of hikers, horses, motorcycles and offroad bicycles on mountain trails in Montana. Mountain Research and Development, 1994.v 14, no1, p.77-88. 
Impactos ambientais em trilhas: agricultura X Ecoturismo - um estudo de caso na Trilha do Quilombo

\section{Notas}

${ }^{1} \mathrm{O}$ maciço da Pedra Branca corresponde a cota altimétrica acima de $50 \mathrm{~m}$.

2 Relatório entregue à administração do PEPB, intitulado "Vistoria do Incêndio Florestal Ocorrido na Pedra do Quilombo em Junho de 2005 - Parque Estadual da Pedra Branca", realizado Rogério Hoesberg.

${ }^{3}$ Um projeto conjunto entre o Instituto Nacional de Colonização e Reforma Agrária INCRA e a Organização das Nações Unidas para a Alimentação e a Agricultura FAO, iniciado em 1995, baseado nos microdados do IBGE, define um estabelecimento integrante da agricultura familiar todo aquele que for dirigido pelo próprio produtor rural e que utiliza, predominantemente, a mão-de-obra familiar ao invés da contratada.

Origem do trabalho: este artigo foi derivado da monografia de graduação em Geografia (Departamento de Geografia Física - Instituto de Geografia - UERJ) de Beatriz Pereira Triane e defendida em março de 2008, sob a orientação da Profa. Dra. Nadja Maria Castilho da Costa e co-orientação da Profa. Dra. Vivian Castilho da Costa, sob o título "Efeitos do Pisoteio de eqüinos no solo de trilhas em Unidades de Conservação: um estudo de caso da trilha do Quilombo - PEPB/RJ".

Agradecimentos: Ao PET de Geografia - UERJ pela bolsa fornecida a Beatriz Pereira Triane durante a sua graduação.

Vivian Castilho da Costa: Departamento de Geografia Física (Instituto de Geografia) da Universidade do Estado do Rio de Janeiro - UERJ

Email: vivianuerj@gmail.com,

Link para o currículo Lattes: http://lattes.cnpq.br/3181407490194397

Beatriz Pereira Triane: Programa de Engenharia Civil (PEC) da COPPE Universidade Federal do Rio de Janeiro - UFRJ

Email: beatriz_triane@yahoo.com.br

Link para o currículo Lattes: http://lattes.cnpq.br/3535531182588755

Nadja Maria Castilho da Costa: Departamento de Geografia Física (Instituto de Geografia) da Universidade do Estado do Rio de Janeiro - UERJ

Email: nadjacosta@pq.cnpq.br

Link para o currículo : http://lattes.cnpq.br/8646672305430213

Data de submissão: 09 de junho de 2008

Data do aceite: 05 de setembro de 2008 